\title{
Opinie
}

\section{Handhavingsbeleid financiële toezichthouders}

\author{
Arnt Mein*
}

De financiële toezichthouders, de AFM en DNB, actualiseren hun handhavingsbeleid. De herziene versie moet beter aansluiten bij de huidige toezichtpraktijk, aldus de toezichthouders. Het vigerende beleid dateert immers al van 2008. ${ }^{1}$ Belanghebbenden zijn tot 2 maart jongstleden in de gelegenheid gesteld te reageren op een conceptversie die kon worden gedownload van de websites van de toezichthouders. Ik vind de versie die nu voorligt nog onvoldoende houvast bieden. In het onderstaande licht ik dat toe.

Allereerst zet ik de belangrijkste elementen van het voorgenomen handhavingsbeleid (hierna het beleid) kort uiteen. Algemeen uitgangspunt is dat betrokkenen zich uit eigen beweging aan de voorschriften houden. Hierop is het toezicht dan ook in eerste instantie gericht. Daarnaast is het toezicht risicogebaseerd. Dat wil zeggen dat voorrang wordt gegeven aan risico's die op basis van marktanalyses als hoog worden gekwalificeerd. Verder spelen daarbij ook inzichten uit zogenoemd gedrag- en cultuuronderzoek een rol. Indien onvoldoende sprake is van spontane naleving, moet vervolgens de inzet van handhavingsinstrumenten normconform gedrag bewerkstelligen. Het gaat dan om informele (een brief of een gesprek) of formele instrumenten (bestuurlijke sancties). De toezichthouders stellen in dit verband, na een afweging van relevante belangen en in het licht van hun specifieke taakstelling, zelfstandig een keuze te maken voor een passende interventie.

\footnotetext{
* Mr. dr. A.G. Mein is lector Legal Management aan de Hogeschool van Amsterdam, Faculteit Maatschappij en Recht en redactielid van Tiidschrift voor Toezicht.

1. Stcrt. 2008, 132.
}

\section{Uitgangspunten en factoren}

Bij de inzet van eerdergenoemde instrumenten zijn specifieke uitgangspunten en factoren richtinggevend, aldus het beleid. Zo wordt een zestal uitgangspunten en drietal factoren opgesomd. De uitgangspunten hebben betrekking op het doel en de wijze van inzet van de handhavingsinstrumenten. Bijvoorbeeld dat niet wordt gedoogd, dat maatwerk wordt geleverd en dat algemene beginselen van behoorlijk bestuur in acht worden genomen. Wat betreft de factoren gaat het om de ernst en duur van de overtreding, de mate van verwijtbaarheid en de compliance-gerichtheid van de overtreder. Vervolgens wordt een (niet-limitatieve en niet-imperatieve) opsomming gegeven van maar liefst zeventien aspecten die daarbij kunnen worden meegewogen. Het betreft in feite een uitwerking van eerdergenoemde factoren. Tot slot wordt de wettelijke beginselverplichting tot volledige openbaarmaking van de bestuurlijke sanctie uiteengezet en beloven de toezichthouders zo veel mogelijk transparant te zijn over de inzet van handhavingsinstrumenten in bijvoorbeeld jaarverslagen en nieuwsbrieven.

\section{Algemeen en vrijblijvend}

Mijn eerste indruk van het beleid is dat het erg algemeen en vrijblijvend is geformuleerd. Het is vooral richtinggevend en geenszins bindend. ${ }^{2}$ Dit roept meteen

2. Toen ik in het kader van mijn promotieonderzoek naar het gebruik van de bestuurlijke boete in de praktijk van het financieel toezicht het handhavingsbeleid van de AFM en DNB analyseerde, viel mij dit ook al op. Het leek daardoor geen wezenlijke rol te spelen in de onderbouwing van de boetebesluiten van de financiële toezichthouders: A.G. Mein, De boete uit balans. Het gebruik van de bestuurlijke boete in de praktijk van het financieel toezicht (diss. Rotterdam), Den Haag: Boom Lemma uitgevers 2015. 
de vraag op naar de toegevoegde waarde ervan. Wat schiet de onder toezicht gestelde hiermee op? Dat geldt ook voor degenen die het beleid van de financiële toezichthouders kritisch volgen. Hoe kan dit stuk nu als ijkpunt dienen in het kader van de beloofde verantwoording over de inzet van handhavingsinstrumenten?

Bij nadere bestudering vroeg ik mij af wat er nu precies veranderd is. Ik heb het beleid uit 2008 er nog eens bij gepakt en moet vaststellen dat het concept voor de nieuwe versie inhoudelijk nauwelijks afwijkt van de huidige. De uitgangspunten en factoren zijn min of meer dezelfde, wel zijn ze anders geordend en soms net iets anders omschreven. Zo neemt openbaarmaking een prominentere plaats in, gelet op eerdere wijzigingen van het openbaarmakingsregime. ${ }^{3}$ Het stuk is hierdoor wel duidelijker en consistenter geworden. Nieuw is, voor zover ik het goed zie, dat (kort) wordt stilgestaan bij het Europese kader waarin het toezicht tegenwoordig wordt uitgeoefend en bij het gebruik van alternatieve toezichtmethoden, zoals onderzoek naar het gedrag en de cultuur binnen de organisaties die onder toezicht staan. Dit laatste vorm van toezicht is zeker vernieuwend en over de plaats en rol ervan hadden de toezichthouder wel mogen uitweiden.

\section{Gemiste kans}

Ik vind deze versie van het handhavingsbeleid onder toezicht gestelden onvoldoende houvast bieden. Door eerdergenoemde factoren verder te verduidelijken evenals het gewicht dat daaraan wordt toegekend, hadden de toezichthouders meer licht kunnen laten schijnen op hun besluitvorming over het inzetten van hun handhavingsinstrumenten. ${ }^{4}$ Een proces dat tot nu toe veel weg heeft van een black box. Hoe lang moet een overtreding bijvoorbeeld hebben geduurd, welk gewicht moet worden toegekend aan beëindiging van de overtreding uit eigen beweging, hoe groot moet het verkregen voordeel zijn of de benadeling van derden? ${ }^{5}$ Ik begrijp wel dat de toezichthouders zich vooraf zo min mogelijk willen vastleggen, maar het zou wel ten goede komen aan de voorspelbaarheid en de rechtszekerheid. Verder hadden de financiële toezichthouders de gelegenheid kunnen aangrijpen duidelijk te maken wat hun visie is op het hedendaagse financieel toezicht en in het bijzonder de rol die de inzet van hun handhavingsinstrumenten daarbij speelt. Het voorgenomen beleid lijkt

3. Stb. 2014, 253

4. Dat hebben zij in het verleden ook wel in zekere mate gedaan (ik verwijs kortheidshalve naar hun websites), maar dat zie ik niet terug in het voorliggende concept.

5. Zie in dit verband ook S.M.C. Nuijten, 'Toezicht, handhaving en rechtsbescherming: nut en noodzaak van formaliteiten', in: S.M.C. Nuijten en R. Stijnen, Rechterlijke toetsing van besluiten en handelingen van de AFM en DNB: trends en analyses (Preadvies voor de Vereniging voor Financieel Recht 2018), Deventer: Wolters Kluwer 2018, p. 34. En M. Nelemans en C.A. Doets, 'Richting toekomstbestendig handhavingsbeleid van de financiële toezichthouders', Tijdschrift voor Bijzonder Strafrecht \& Handhaving 2020/2, p. 57-62. nog steeds sterk in het teken te staan van klassiek nalevingstoezicht. $\mathrm{Nu}$ is deze vorm van toezicht niet ineffectief, maar tegenwoordig is er meer onder de zon. Zo wordt het toezicht tegenwoordig geacht meer in het teken te staan van 'het borgen en realiseren van publieke belangen'. ${ }^{6}$ Welke rol speelt bijvoorbeeld het gedragsen cultuuronderzoek in dat verband? Ook 'omgevingsgerichte waarden' als transparantie, verantwoording en responsiviteit worden sterker van belang geacht bij het hedendaagse toezicht. ${ }^{7}$ Ik vind het opmerkelijk dat de financiële toezichthouders in dit opzicht (wederom) weinig kleur bekennen. Dat zou wat mij betreft wel degelijk mogen worden verwacht van dit type onafhankelijke en professionele toezichthouders die beschikken over ingrijpende handhavingsinstrumenten. ${ }^{8}$ Het openbaar maken van dit type handhavingsbeleid is in mijn ogen dan ook vooral symbolisch. Het wachten is op de definitieve versie.
6. WRR, Toezien op publieke belangen. Naar een verruimd perspectief op rijkstoezicht, Amsterdam: Amsterdam University Press 2013.

7. M. Bokhorst en J. van Erp, Van transparantie naar responsiviteit. Ontwikkeling van omgevingsgerichtheid van toezichthouders, Utrecht: USBO 2017 en J. van Erp en M. van der Steen, Wetenschapsagenda Toezicht, Utrecht: USBO 2018.

8. Vgl. M. Aelen, Beginselen van goed markttoezicht. Gedefinieerd, verklaard en uitgewerkt voor het toezicht op financiële markten (diss. Utrecht), Den Haag: Boom Juridische uitgevers 2014. 